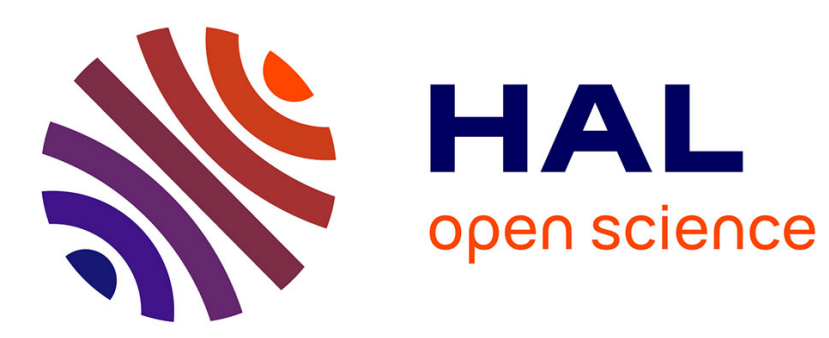

\title{
Free Tools to Help Blind People with Musical Learning Nadine Jessel
}

\section{To cite this version:}

Nadine Jessel. Free Tools to Help Blind People with Musical Learning. 14th International Conference on Computers Helping People with Special Needs (ICCHP 2014), Jul 2014, Paris, France. pp.596-601, 10.1007/978-3-319-08596-8_92. hal-03246620

\section{HAL Id: hal-03246620 \\ https://hal.science/hal-03246620}

Submitted on 3 Jun 2021

HAL is a multi-disciplinary open access archive for the deposit and dissemination of scientific research documents, whether they are published or not. The documents may come from teaching and research institutions in France or abroad, or from public or private research centers.
L'archive ouverte pluridisciplinaire HAL, est destinée au dépôt et à la diffusion de documents scientifiques de niveau recherche, publiés ou non, émanant des établissements d'enseignement et de recherche français ou étrangers, des laboratoires publics ou privés. 


\title{
Free Tools to Help Blind People with Musical Learning
}

\author{
Nadine Jessel \\ IRIT, Université Paul Sabatier, Toulouse, France \\ baptiste@irit.fr
}

\begin{abstract}
This paper describes solutions to improve the access to music for blind people. These solutions are proposed during the European project $\mathrm{Mu}$ sic4VIP. The objective of the project is to help teacher to teach music to blind pupils and to create tools which will enable blind people to learn music independently. A method base on SUS questionnaire is described and used to have a quick feedback for users. These first results indicate that users perceive our solution as good but these results have to be consolidated with further surveys with a large number of respondents.
\end{abstract}

\section{Introduction}

As Antonio Quatraro said in 2009, during the conference for the Commemoration of the Bicentenary of Louis Braille's Birth, access to music for blind people is on the decrease. We can see this clearly in a moving film, Braille - My Musical Language, [2] in which three Blind musicians, through their own stories emphasize the importance of Braille Music. Music is the only totally accessible art for blind people but it is difficult for them to learn it. In the past, music was learnt in specialized schools and a lot of blind people became very good musicians or at least gained a good musical culture. Due to the decrease of specialized schools and the integration of blind people into mainstream schools their musical education is poor. Braille music is not widely taught because music teachers are reluctant to learn it themselves. At the same time, the number of people who are able to transcribe musical scores in Braille is also on the decrease so it is difficult to find musical scores in Braille. This alarming situation requires the help of computer tools to transcribe, edit and read musical scores.

This paper describes the solutions proposed by the European project Music4VIP. In the first part of this project we researched the requirement and the current state of the art for accessible music. In the second part we describe the Music4VIP solutions that will enable teachers to teach music to blind pupils and tools which will enable blind people to learn music independently. Finally, we propose a methodology for the evaluation of these tools and didactic solutions.

\section{Requirement and State of the Art}

Based on the analysis of the results of the questionnaire carried out during the first step of the project music4VIP we can structure the requirement in six following areas: 
- Students, Teachers and Music Schools: For children at a young age it is important to encourage them to study music and introduce soon and step by step the use of Braille music. With the help of IT technology children can use easily Braille but the problem is the teacher who is not up-to-date with IT technologies in this specific area. Teacher need training courses to adapt their teaching methods, to communicate with Blind children and to give equal importance to studying by ear than to learning by reading Braille music.

- Availability of Braille Texts: It is necessary to obtain Braille score easily which correspond as precisely as possible to the print editions but also which can be manage and reduce following the user needs.

- Braille Music and Informatics [IT]: Numerous software exist for editing music for sighted people, most of them use MusicXML and Midi to code a musical score. To exchange musical score and to produce them quickly in Braille, it is necessary to use software making the conversion of scores from Braille music into staff notation and vice versa. A computer program to manage and edit Braille score helps blind teacher or blind student to exchange their production with sighted musicians. Hear and read the music on the same system is important to facilitate the memorization. Most people prefer embossed copies when they read musical score but some of them prefer to use a computer when they read Braille music. The program should support some presentation customizations such as presentation section by section or bar over bar. The software should be easy to use with a simple documentation, using shortcuts and should be accessible using screen reader technology.

- Web Service: As it exists for Braille text, the creation of an international Braille music catalogue should permit to find quickly Braille musical scores produce in several countries and to improve the communication between production centers.

Braille music syntax: The Braille music syntax is well defined in the new international manual of Braille music notation [3] but some dialects exist, it is a complex syntax because it depends of the context and Braille music is a linear code which not permits to Blind people to have a complete vision of a music score. The Braille music in electronic form contains Braille and Midi information so it is easy to hear and read the musical information, the electronic form permits to read the Braille music using a screen reader.

- Support for Braille Music Pedagogy: It is important to adapt the pedagogy to get an overall picture of the score, to re-duce the reading speed, to not refer to the musical information with the visual aspect.

Responding to this different requirement, we propose the solutions defined and realized during the Music4VIP project. A proposal of evaluation of the usability of these solutions will be explain and the results will be analyzed.

\section{$3 \quad$ Music4VIP Solutions}

The Music4VIP project aims to develop the best possible use of new technologies to help with the teaching and learning of Braille music. We propose some free technical tools as well as some guidelines and videos which can help teachers to teach music to blind students. 


\subsection{Technical Tools}

Thanks to the previous work done during the Contrapunctus project [4] to create a code able to code musical information in Braille (BMML Braille Music Markup Language) [5] we propose a number of free tools to manage musical information in Braille. BMML has been designed to code the structure and content of music Braille notation according to the New International manual of Braille Music Notation. BMML facilitates the conversion to and from other music notation codes and permits the flexibility to code Braille music variants.

We have developed a free online conversion module which is able to convert a MusicXML file score into BMML and vice versa. This module is accessible for blind people using a screen reader and very easy to use also for teachers who want to produce Braille music files.

We also offer free software called BMR (Braille Music Reader) which can read BMML files and facilitates the reading of musical information in Braille, by sound and in spoken form. With BMR the musician can explore the score, hide some parts or elements and access all the musical information. BMR has the same functionality to read a score as BME (a commercial product) [6] which can also edit a score in Braille.These different tools are necessary but not sufficient to help blind people in their musical learning. We propose some guidelines, video and pedagogical scenarios to help teachers and students in their use.

\subsection{Pedagogical Aids and Scenarios}

We propose several video lessons and choose to present four of them which aim to help a sighted teacher to teach music for blind student.

The first video gives a history of Braille notation and several principles for normal text.

The second video addresses the theme of the musical education of young blind people, with particular reference to aural teaching within musical studies. In this video we talk about perception and classification of various sounds, focusing on the main similarities and differences between auditory perception and perception based on data coming from other sensory canals (sight, smell, touch).

The third video proposes guidelines for efficient and effective communication with blind students.

The fourth video describes Braille music principles and computer tools that facilitate the management of musical scores.

Having viewed these lessons a teacher will be able to teach blind pupils more efficiently.

Teachers have to adapt their teaching and the following scenarios can help. We propose for example a scenario to teach a song and one to construct a didactical unit for a piano student. In each case the teacher has to prepare the score in MusicXML or in BMML using the transcription module and send them to their blind pupils. The first scenario is a suggested lesson plan designed to teach the two-voice "Ode to Joy" to a class. The second scenario describes practice strategies for developing agility at the piano, based on Hanon's exercises. 
We also propose a music theory book and some acoustics lessons with examples in BMML which can be studied directly and independently by blind pupils or with the help of a teacher.

To evaluate the usability of our different tools and guidelines we propose to use the SUS (system usability scale) [7] questionnaire which is very simple (10 questions) but efficient to provide subjective feedback for the users. We focus our attention on two groups of users, one composed of teachers and one of blind music students.

\subsection{Methods and Results of This Questionnaire}

We use the SUS (System Usability Scale) which is a very simple questionnaire based on 10 items with a scale from 1 to 5 based on Likert scale. The Likert scale is based on forced-choice questions which indicate the degree of agreement or disagreement with the statement. Table 1 shows the adapted SUS.

Table 1. Adapted SUS

\begin{tabular}{|c|c|c|c|c|c|c|}
\hline & & $\begin{array}{l}\text { Strongly } \\
\text { disagree }\end{array}$ & & & & $\begin{array}{l}\text { Strongly } \\
\text { agree }\end{array}$ \\
\hline 1 & $\begin{array}{l}\text { I think that I would like to use this } \\
\text { system frequently }\end{array}$ & 1 & 2 & 3 & 4 & 5 \\
\hline 2 & $\begin{array}{l}\text { I found the system unnecessarily } \\
\text { complex }\end{array}$ & 1 & 2 & 3 & 4 & 5 \\
\hline 3 & I thought the system was easy to use & 1 & 2 & 3 & 4 & 5 \\
\hline 4 & $\begin{array}{l}\text { I think that I would need the support } \\
\text { of a technical person to be able to use } \\
\text { this system }\end{array}$ & 1 & 2 & 3 & 4 & 5 \\
\hline 5 & $\begin{array}{l}\text { I found the various functions in this } \\
\text { system were well integrated }\end{array}$ & 1 & 2 & 3 & 4 & 5 \\
\hline 6 & $\begin{array}{l}\text { I thought there was too much incon- } \\
\text { sistency in this system }\end{array}$ & 1 & 2 & 3 & 4 & 5 \\
\hline & $\begin{array}{l}\text { I would imagine that most people } \\
\text { would learn to use this system very } \\
\text { quickly }\end{array}$ & 1 & 2 & 3 & 4 & 5 \\
\hline 8 & $\begin{array}{l}\text { I found the system very cumbersome } \\
\text { to use }\end{array}$ & 1 & 2 & 3 & 4 & 5 \\
\hline 9 & I felt very confident using the system & 1 & 2 & 3 & 4 & 5 \\
\hline 10 & $\begin{array}{l}\text { I needed to learn a lot of things before } \\
\text { I could get going with this system }\end{array}$ & 1 & 2 & 3 & 4 & 5 \\
\hline
\end{tabular}

- For the teachers we propose two questionnaires: In the first questionnaire we change "the system" to "the video lessons" and delete the question 5 because in this case it will make no sense. For this questionnaire concerning video lesson the score of question 5 is calculated with 3.

- For the second questionnaire we change "the system" to "the conversion module". 
- In the questionnaire for the students we change "the system" to "BMR" (Braille Music Reader).

Perhaps we have also to add a questionnaire for the students with the conversion module because in some cases the teacher gives them a MusicXML file and the student has to make the conversion.

At the present time, we are not asking for feedback concerning the conversion module because there remain some problems with the version of MusicXML files and with some MusicXML files found on the web. The conversion module frequently responds it is not an XML file.

So, we focus our attention on the teachers' answers concerning the video lessons and the students' answers concerning the BMR module.

To calculate the SUS score, as indicated in [7], we sum the score contributions from each item and multiply the sum of the scores by 2.5 to obtain the overall value of SUS. SUS scores have a range of 0 to 100.

For items 1,3,5,7 and 9 the score contribution is the scale position minus 1 .

For items 2,4,6,8 and 10, the score contribution is 5 minus the scale position.

We analyze the results with the help of the result done in the figure 1 in the article [7] which qualifies the SUS score with adjective rating.

Table 2. SUS Score and adjective rating

\begin{tabular}{ll}
\hline SUS Score & Adjective Rating \\
\hline SUS score $<25$ & Worst imaginable \\
$25<$ SUS score $<38$ & Poor \\
$48<$ SUS score $<52$ & OK \\
$52<$ SUS score $<72$ & Good \\
$72<$ SUS score $<85$ & Excellent \\
$85<$ SUS score & Best imaginable \\
\hline
\end{tabular}

We have very few answers (less than ten for each questionnaire) but all of them qualify as Good or Excellent.

- For the teachers' questionnaire the average is 75 and the answers are in the range 70-80 which puts the responses between Good and Excellent. The open question at the end of the questionnaire contains no answers.

- For the student questionnaire the average is 77 with range of [75-80].

Several suggestions appear in the open question such as:

- BMR is better for beginners

- BMR runs well with Jaws and NVDA

- I need help with my Braille table to manage my Braille display.

These first results indicate that users perceive our solution as good but these results have to be consolidated with further surveys with a large number of respondents. 


\section{Conclusion}

We propose several tools and guidelines to facilitate Blind pupils in their musical studies. All the tools are free and teaching material is in CC BY-NC creative commons licenses. As the copyright laws concerning musical scores are not the same in different European countries each teacher must choose which scores to convert into Braille. The work done has to be tested on a large scale but the preliminary tests, explained in this article, are good. It will be useful to create an open archive in which each teacher or student can exchange their lessons and can comment on the lessons proposed by others. In this case, it is necessary to add metadata information in LOM (learning object metadata) [8] format to use a research engine efficiently to find spe-cific resources for class teaching or individual teaching. This prospect is not so easy due to the multilingual and different musical curricula in the different European countries.

Acknowledgements. Part of this work have been undertaken in the European project Music4VIP, I have to thanks all the partners of the project.

\section{References}

1. Music4VIP, http://www.music4vip.org

2. Braille - My Musical Language, http: / /www. nota.nu/braillefilm

3. Braille Music Notation, https: //archive.org/details/newinternationaloobett

4. Contrapunctus project, http://www. punctus.org

5. Encelle, B., Jessel, N., Mothe, J., Ralalason, B., Asensio, J.: BMML: Braille Music Markup Language. The Open Information Systems Journal 2009(3), 123-135 (2009)

6. BME, http://www.veia.it/en/bme2_product

7. SUS - System Usability Scale, http://www.usabilityprofessionals.org/upa_publications/jus/2 013 february/JUS_Brooke_February_2013.pdf

8. LOM - Learning Object Metadata, http: / / hmab. cs. kuleuven. be/publications / files/Lorsurvey . pdf 